\title{
RANCANG BANGUN SISTEM E-TRACER STUDY ALUMNI UNTUK MENGETAHUI OUTCOME PENDIDIKAN BERBASIS WEB MOBILE
}

\author{
Dini Agustin ${ }^{1)}$, Deni Apriadi ${ }^{3)}$ \\ Sistem Informasi, STMIK Bina Nusantara Jaya Lubuklinggau \\ Jl. Yos Sudarso No.97 A Kel. Jawa Kanan, Kota Lubuklinggau, Sumatera Selatan \\ diniagustin.bnj@gmail.com ${ }^{1)}$,denidrv@gmail.com ${ }^{3)}$
}

\begin{abstract}
Alumni are an important part of the information they need to explore, to find out their existence after graduating from an educational institution. Tracer study is an alumni tracking study that aims to find out how far the achievement of the vision and mission of an educational institution is. Tracer study is very important to know what activities alumni do and monitor their development and their ability to be competent in the world of work. At the Faculty of Agriculture, Musi Rawas University, tracer studies have a problem, namely when collecting data. Besides that the problem lies with the respondent / alumni where they are reluctant to fill out the questionnaire with their respective reasons. Therefore, it is necessary to have an integrated alumni e-tracer study system that runs online which allows alumni to fill out questionnaires online. This system is mobile web based so that it can be accessed via mobile devices, anytime and anywhere as long as it is connected to the internet network. Mobile web-based can later attract respondents quickly, easily, and efficiently so that feedback increases. With this system, it is hoped that later it will facilitate the implementation of tracer studies and at the same time as a medium for sharing information about the world of work and other news.
\end{abstract}

Keywords: Alumni, Tracer Study, Web Mobile

\begin{abstract}
Abstrak
Alumni merupakan bagian penting yang harus digali informasinya, untuk mengetahui eksistensi mereka setelah lulus dari lembaga pendidikan. Tracer study merupakan studi pelacakan alumni yang bertujuan untuk mengetahui sejauh mana pencapaian visi dan misi dari sebuah lembaga pendidikan. Hal ini juga dilakukan untuk mengetahui kegiatan yang alumni lakukan dan memantau perkembangan \kemampuan mereka dalam berkompetensi di dunia kerja. Pada Fakultas Pertanian Universitas Musi Rawas tracer study memiliki masalah pada saat pengumpulan data. Selain itu masalah terletak pada responden/alumni di mana mereka malas mengisi kuisioner dengan alasan masing-masing. Oleh sebab itu dibutuhkan sistem e-tracer study alumni yang terintegrasi dan berjalan secara online yang memungkinkan alumni melakukan pengisian kuisioner secara online. Sistem ini berbasis web mobile sehingga dapat diakses melalui perangkat mobile, kapan saja dan dimana saja selama terhubung dengan jaringan internet. Dengan berbasis web mobile nantinya dapat menarik responden secara cepat, mudah, dan efisien sehingga feedback pun meningkat. Dengan sistem ini diharapkan nantinya dapat memudahkan pelaksanaan tracer study dan sekaligus sebagai media untuk sharing informasi seputar dunia kerja dan berita lainnya.
\end{abstract}

Kata kunci : Alumni, Tracer Study, Web Mobile

\section{Pendahuluan}

Alumni merupakan bagian penting yang harus digali informasinya, untuk mengetahui eksistensi mereka setelah lulus dari lembaga pendidikan. Informasi yang diberikan alumni sangat berperan penting terhadap keberhasilan dan kemajuan dari lembaga pendidikan itu sendiri. Kegiatan menggali informasi dari alumni dinamakan dengan tracer study alumni.Menurut Menurut Bakti, Noval, dan Aji, Tracer study merupakan sebuah upaya yang diharapkan dapat menyediakan informasi untuk mengevaluasi hasil pendidikan. Informasi ini digunakan untuk pengembangan lebih lanjut dalam menjamin kualitas pendidikan. [2]

Jurnal Ilmiah Binary STMIK Bina Nusantara Jaya

Vol. 01 No. 01 Tahun 2019, ISSN : 2657- 2117 
Tracer study sangat penting dilakukan guna mendapatkan informasi dari alumni berkaitan dengan outcome pendidikan yang meliputi kesesuaian ilmu yang didapat pada saat kuliah dalam dunia kerja, kegiatan apa yang alumni lakukan dan sejauh mana perkembangan mereka, kemampuan mereka dalam berkompetensi di dunia kerja. Informasi ini nantinya digunakan untuk mengevaluasi kinerja lembaga itu sendiri dan untuk meningkatkan kualitas pendidikan di masa depan. Selain itu tracer study dilakukan untuk memenuhi salah satu syarat kelengkapan akreditasi oleh Badan Akreditasi Nasional Perguruan Tinggi (BAN-PT).

Universitas Musi Rawas merupakan perguruan tinggi yang melakukan tracer study 1 tahun sekali. Pada Fakultas Pertanian masalah yang dihadapi dalam melakukan tracer study yaitu pada saat pengumpulan data. Dimana pengumpulan data dilakukan dengan cara menyebar kertas kuisioner. Kuisioner disebarkan melalui mahasiswa yang melakukan Kuliah Kerja Praktek Lapangan (KKPL) dan pada saat dinas di tempat alumni bekerja. Berdasarkan data yang diperoleh bahwasannya dari 100 eksemplar yang disebarkan ke alumni hanya 60 eksemplar yang diterima kembali oleh pihak kampus. Penyebaran kertas kuisioner seperti ini dinilai kurang optimal karena tidak menjangkau semua alumni. Selain itu masalah juga terletak pada responden/alumni, dimana responden/alumni tidak mengisi kuisioner dengan alasan masing-masing sehingga menyebabkan sedikitnya jumlah kuisioner yang diterima kembali oleh Fakultas Pertanian.

Oleh karena itu penelitian bertujuan untuk merancang dan membangun sistem e-tracer study alumni pada Fakultas Pertanian Universitas Musi Rawas berbasis web mobile sehingga dapat diakses dimana saja dan kapan saja melalui perangkat mobile.

\section{Tinjauan Pustaka}

\subsection{Tracer Study}

Menurut Bakti, Noval, dan Aji [2], Tracer study merupakan sebuah upaya yang diharapkan dapat menyediakan informasi untuk mengevaluasi hasil pendidikan. Informasi ini digunakan untuk pengembangan lebih lanjut dalam menjamin kualitas pendidikan.

Tracer study dinilai penting karena menjadi alat evaluasi kinerja PT dan sekarang telah dijadikan salah satu syarat kelengkapan akreditasi oleh Badan Akreditasi Nasional Perguruan Tinggi (BAN-PT), sebagai kelengkapan dalam dokumen evaluasi diri yang diperlukan dalam pengajuan proposal melalui Kemdikbud. Tracer study online Dikti ditujukan untuk melacak jejak lulusan/alumni yang dilakukan 2 tahun setelah lulus dan bertujuan untuk mengetahui:

1) Outcome pendidikan dalam bentuk transisi dari dunia pendidikan tinggi ke dunia kerja (termasuk masa tunggu kerja dan proses pencarian kerja pertama), situasi kerja terakhir, dan aplikasi kompetensi di dunia kerja.

2) Output pendidikan yaitu penilaian diri terhadap penguasaan dan pemerolehan kompetensi.

3) Proses pendidikan berupa evaluasi proses pembelajaran dan kontribusi pendidikan tinggi terhadap pemerolehan kompetensi.

Hasil tracer study akan membantu PT dalam mengetahui posisi lulusan yang telah terserap dalam dunia kerja serta menyiapkan lulusan sesuai dengan kompetensi yang diperlukan dunia kerja. Hasil tracer study yang dilaporkan ke Dikti akan membantu program Pemerintah dalam rangka pemetaan kebutuhan dunia kerja dengan pembangunan pendidikan di Indonesia.[3]

\subsection{Alumni}

Dalam Kamus Besar Bahasa Indonesia (KBBI) alumni adalah orang-orang yang telah mengikuti atau tamat dari suatu sekolah atau perguruan tinggi.[4]

\subsection{Outcome Pendidikan}

Outcome pendidikan adalah efek jangka panjang yang dihasilkan dari proses pendidikan misalnya penerimaan di pendidikan tingkat lanjut, prestasi dan pelatihan berikutnya, peluang kerja, penghasilan serta prestise lebih lanjut. Dalam definisi lain outcome merupakan hasil yang terjadi setelah pelaksanaan kegiatan jangka pendek. Outcome lebih mencakup kepada hasil yang harus tercapai dalam jangka pendek, menengah dan jangka panjang dalam berbagai aspek: (1) pembelajaran, (2) aksi dan (3) kondisi yang diharapkan. [5]

\subsection{Web Mobile}

Aplikasi web mobile merupakan lanjutan dari aplikasi web tradisional. Saat anda online menggunakan smartphone, tablet, atau komputer, tampilannya akan beradaptasi sesuai perangkat yang digunakan. Desain yang fleksibel ini memaksimalkan kemampuan web browser yang digunakan di perangkat mobile anda. Memang tidak semua ponsel memilki akses internet, tapi dengan melihat trend yang berkembang, bisa dikatakan dalam waktu dekat semua ponsel akan 
mempunyai akses internet. Mobile Websites (Situs Web Mobile) merupakan situs web yang dirancang khusus untuk perangkat mobile. Situs Web Mobile desainnya sederhana dan biasanya bersifat memberikan informasi.[6]

\section{Teori Pendukung Perancangan}

\section{Unified Modeling Language (UML)}

Menurut Rosa A.S and Shalahuddin [7], Unified Modeling Language (UML) merupakan sebuah standarisasi bahasa pemodelan untuk membangun perangkat lunak yang menggunakan teknik pemrograman berorientasi objek. UML muncul karena adanya kebutuhan pemodelan visual untuk menspesifikasikan, menggambarkan, mebangun, dan dokumentasi dari sistem perangkat lunak. UML merupakan bahasa visual untuk pemodelan dan komunikasi mengenai sebuah sistem dengan menggunakan diagram dan teks-teks pendukung.

\section{Diagram UML}

Menurut Rosa A.S dan Shalahuddin, pada UML 2.3 ada 13 macam diagram yang dikelompokkan dalam 3 kategori.

Berikut ini penjelasan singkat dari pembagian kategori tersebut:

1) Structure diagrams yaitu kumpulan diagram yang digunakan untuk menggambarkan suatu struktur statis dari sistem yang dirancang.

2) Behavior diagram yaitu kumpulan diagram yanng digunakan untuk menggambarkan kelakuan sistem atau rangkaian perubahan yang terjadi pada sebuah sistem.

3) Interactions diagrams kumpulan diagram yang digunakan untuk menggambarkan interaksi antar sistem maupun interaksi antar subsistem pada suatu sistem.

\section{Use Case Diagram}

Menurut Rosa A.S and Shalahuddin, Use case atau diagram use case merupakan pemodelan untuk kelakuan (behavior) sistem informasi yang akan dibuat. Use case menggambarkan sebuah interaksi antara satu atau lebih aktor dengan sistem informasi yang akan dibuat.

\section{Metodologi Penelitian}

3.1. Metode Pengembangan Sistem
Metode pengembangan sistem pada penelitian ini yaitu menggunakan metode waterfall. Menurut Rosa model SDLC air terjun (waterfall) sering juga disebut model sekuensial linier (sequential linier) atau alur hidup klasik (classic life cycle). Model air terjun menyediakan pendekatan alur hidup perangkat lunak secara sekuensial atau terurut dimulai dari analisis, desain, pengkodean, pengujian, dan tahap pendukung (support).

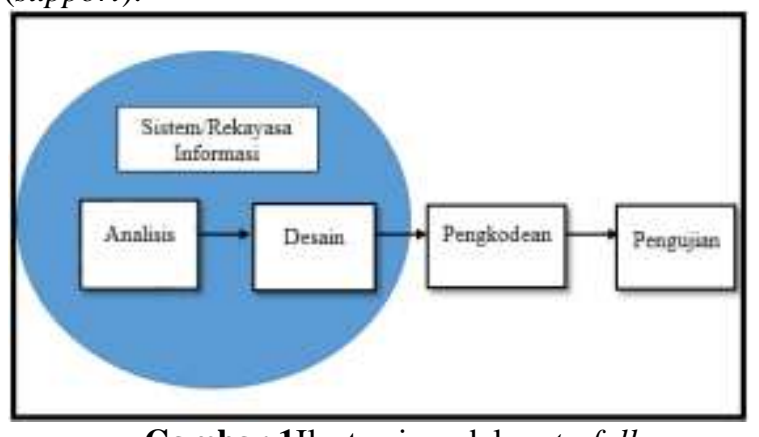

Gambar 1Ilustrasi model waterfall

\subsection{Pengujian Black-Box Testing}

Menurut Rosa A.S and Shalahuddin, black box testing (pengujian kotak hitam) yaitu menguji perangkat lunak dari segi spesifikasi fungsional tanpa menguji desain dan kode program. Pengujian dimaksudkan untuk mengetahui apakah fungsi-fungsi, masukan, dan keluaran dari perangkat lunak sesuai dengan spesifikasi yang dibutuhkan. Pengujian kotak hitam dilakukan dengan membuat kasus uji yang bersifat mencoba semua fungsi dengan memakai perangkat lunak apakah sesuai dengan spesifikasi yang dibutuhkan.

Black box testing berfokus pada spesifikasi fungsional dari perangkat lunak. Tester dapat mendefinisikan kumpulan kondisi input dan melakukan pengetesan pada spesifikasi fungsional program. Black box testing bukanlah solusi alternatif dari white box testing tapi lebih merupakan pelengkap untuk menguji hal-hal yang tidak dicakup oleh white box testing. [14]

Black Box Testing cenderung untuk menemukan halhal berikut :

1) Fungsi yang tidak benar atau tidak ada.

2) Kesalahan antarmuka (interface errors).

3) Kesalahan pada struktur data dan akses basis data.

4) Kesalahan performansi (performance errors).

5) Kesalahan inisialisasi dan terminasi.

\subsection{Metode Pengumpulan Data}

Dalam melakukan penelitian ini, peneliti menggunakan metode pengumpulan data atau informasi yang 
nantinya akan digunakan dalam penyelesaian masalah. Berikut metode pengumpulan data yang digunakan:

1) Wawancara (interview)

Dalam teknik ini penulis melakukan wawancara secara langsung dengan pihak yang menangani tracer study yaitu ketua Prodi Agribisnis yang mewakili ketua prodi pada Fakultas Pertanian untuk mendapatkan data dan informasi yang sesuai dengan kebutuhan sistem yang akan dibangun.

2) Pengamatan (observasi)

Penulis secara langsung melakukan pengamatan di Fakultas Pertanian Universitas Musi Rawas Lubuklinggau yang berkaitan dengan kegiatan tracer study. Penulis mengamati sistem yang sedang berjalan, dengan tujuan untuk mengetahui permasalahan dan ruang lingkup apa saja dalam pembangunan sistem .

3) Studi Literatur

Penulis melakukan kajian pustaka dari berbagai sumber seperti jurnal, buku, skripsi, dan lainnya untuk mendapatkan teori yang berkaitan dengan permasalahan dan sebagai referensi dalam upaya pemecahan masalah.

\subsection{Analisis Dan Perancangan}

\subsubsection{Analisis Sistem}

Analisis sistem bertujuan untuk mengidentifikasi dan mengevaluasi permasalahan, serta untuk mengetahui hambatan-hambatan yang terjadi dalam kegiatan tracer study alumni pada Fakultas Pertanian Universitas Musi Rawas. Adapun hal-hal yang akan dianalisis pada tahapan ini adalah analisis prosedur kerja, analisis pemecahan masalah, kebutuhan data, kebutuhan fungsional dan kebutuhan non fungsional sistem.

\subsubsection{Analisis Prosedur Kerja}

Analisis sistem merupakan langkah awal dalam membangun suatu sistem yang baru.Dalam langkah ini penulis melakukan analisis prosedur kerja terhadap permasalahan yang ada di Fakultas Pertanian Universitas Musi Rawas mengenai tracer study alumni.

Tracer study merupakan study pelacakan alumni yang memiliki beberapa tujuan diantaranya untuk mengetahui outcome pendidikan. Pada umumnya tracer study dilakukan dengan cara menyebar kuisioner kepada alumni. Tracer study dapat dilakukan dengan dua cara yakni dengan cara offline dan online. Cara offline yakni menyebar dan mengisi kuisioner dengan menggunakan kertas sedangkan cara online yakni menyebar dan mengisi kuisioner melalui sistem, namun pada sistem online memiliki masalah yang terletak pada responden/alumni yakni mereka malas mengisi kuisioner. Untuk itu akan lebih optimal apabila sistem tracer study dilakukan secara elektronik sehingga dapat menjaring semua alumni dan mampu menarik responden/alumni supaya mereka mau mengisi kuisioner. Namun, fakta yang penulis temukan berdasarkan penelitian yang dilakukan di Fakultas Pertanian Universitas Musi Rawas adalah sebagai berikut:

1) Tracer study dilakukan dengan cara menyebar kertas kuisioner.

2) Penyebaran kuisioner melalui mahasiswa yang sedang melakukan Kuliah Kerja Praktek Lapangan (KKPL) dan pada saat dinas di tempat alumni bekerja.

3) Penyebaran kuisioner hanya fokus pada alumni yang sudah bekerja.

4) Feedback responden/alumni cukup baik, dari 100 eksemplar kuisioner yang disebar yang kembali mencapai 60. Data ini diperoleh dari hasil wawancara dengan narasumber yakni Kaprodi Agribisnis.

\subsubsection{Analisis Pemecahan Masalah}

Dengan melihat permasalahan yang dihadapi pada proses kegiatan tracer study alumni pada Fakultas Pertanian Universitas Musi Rawas, maka dibutuhkan suatu sistem tracer study alumni yang terintegrasi yang dapat mengumpulkan dan mengolah serta menyajikan data secara lebih akurat. Guna mendapatkan informasi dari alumni dan memudahkan dalam pengaksesan datanya, maka informasi dapat dirangkum dalam sebuah sistem e-tracer study alumni berbasis web mobile. Sistem ini terintegrasi dan memungkinkan responden/alumni dapat mengisi kuisioner secara online. Web mobile merupakan web yang dapat menyesuaikan perangkat mobile yang digunakan seperti smartphone. Dengan berbasis web mobile artinya adalah responden/alumni dapat mengisi kuisioner secara online dimana saja kapan saja melalui perangkat mobile yang mereka gunakan. Untuk itu, penulis menggunakan web mobile untuk dapat menarik lulusan agar berpartisipsi sebagai responden secara cepat, mudah dan efisien. Selain itu, sistem ini dapat diakses oleh semua alumni jadi tidak hanya fokus pada alumni yang sudah bekerja saja, dengan demikian maka responden/alumni akan meningkat. Dengan sistem ini alumni dapat memberikan saran kepada Fakultas Pertanian Universitas Musi Rawas dan juga dapat digunakan sebagai media yang menyediakan informasi terkait dengan tracer study alumni dan berita lainnya. 
1) Use Case Diagram

Berikut ini merupakan use case diagram pada sistem $e$ tracer study alumni berbasis web mobile.

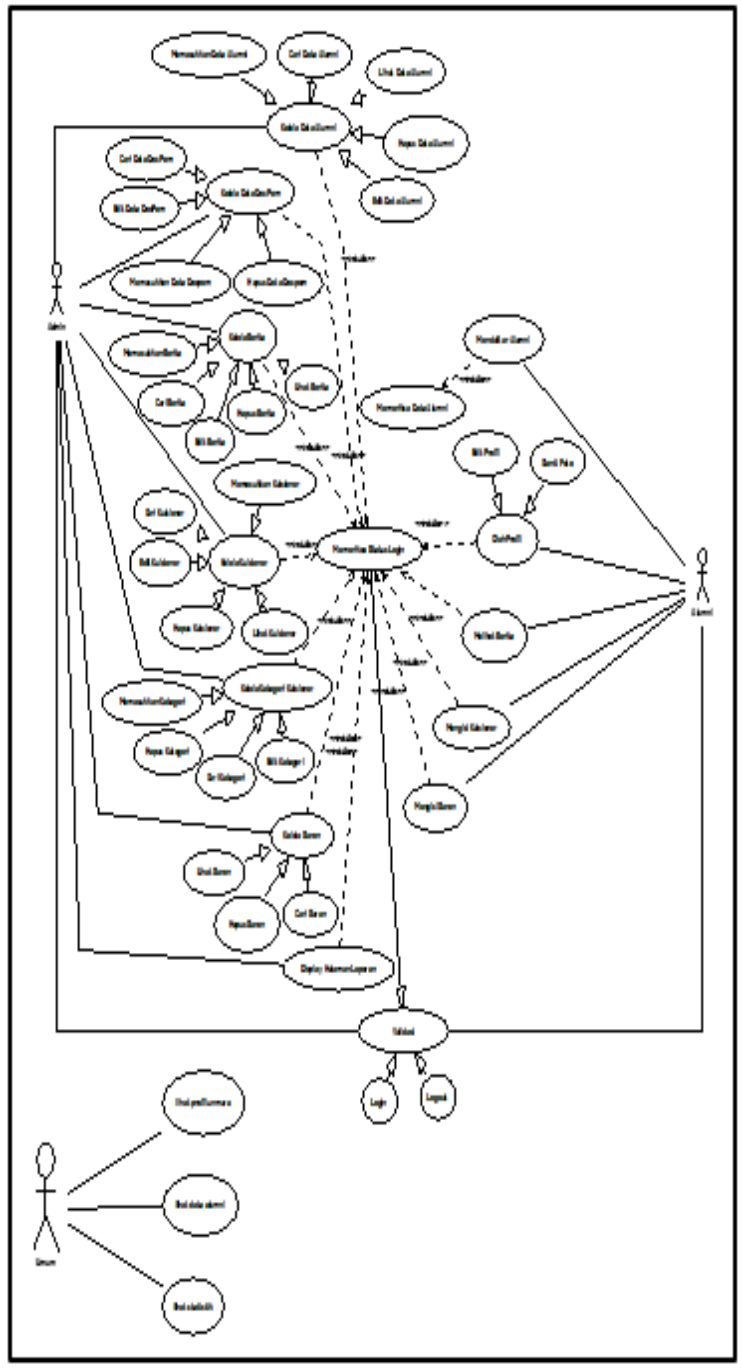

Gambar 2. Use Case Diagram

\section{Hasil Dan Pembahasan}

\subsection{Arsitektur Sistem}

Adapun arsitektur sistem yang digunakan untuk perancangan e-tracer study alumni berbasis web mobile ini adalah sebagai berikut:

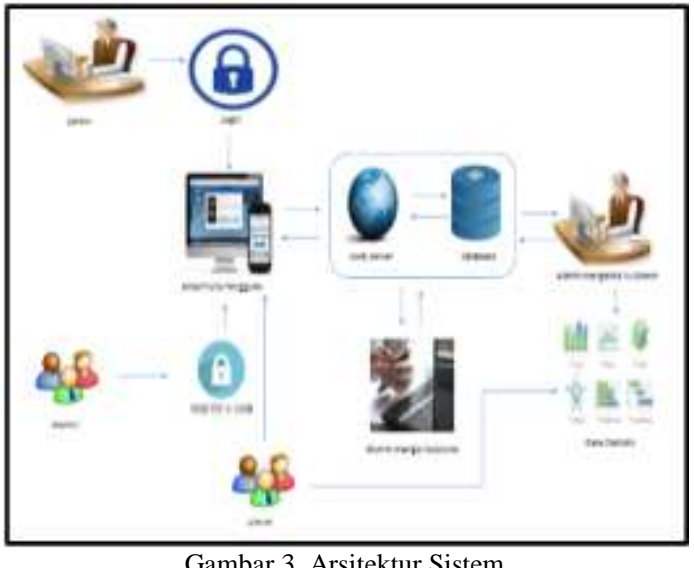

4.2. Implementasi Sistem

Dari hasil dan analisis yang telah diuraikan sebelumnya maka berikut tampilan antarmuka sistem e-tracer study alumni berbasis web mobile. Pada gambar 9 menunjukkan halaman utama user. Halaman utama user merupakan halaman awal saat pertama kali membuka website. Pada halaman ini terdiri dari home, profil unmura, alumni unmura, statistik alumni, daftar, dan login. Halaman ini dapat digunakan oleh pengguna umum atau pengunjung website untuk melihat informasi profil unmura, alumni unmura, dan statistik alumni. Jika user ingin daftar maka klik daftar, jika ingin login maka klik login.

Untuk dapat melihat statistik alumni user dapat membuka menu statistik alumni seperti yang terlihat pada gambar 5. Jika alumni ingin melakukan login maka alumni harus melakukan pendaftaran alumni untuk memiliki username dan password seperti yang terlihat pada gambar 6. Selanjutnya data alumni yang dimasukkan diverifikasi oleh admin melalui sistem. Apabila data sudah benar maka registrasi berhasil. Setelah itu alumni dapat login dengan memasukkan username dan password yang dimiliki, kemudian alumni dapat mengisi kuisioner sesuai dengan keadaan alumni apakah sudah bekerja atau belum. Jika sudah bekerja maka akan masuk ke kriteria kuisioner yang bekerja namun jika belum bekerja maka akan masuk ke kriteria kuisioner belum bekerja seperti yang terlihat pada gambar 7 dan 8 . 


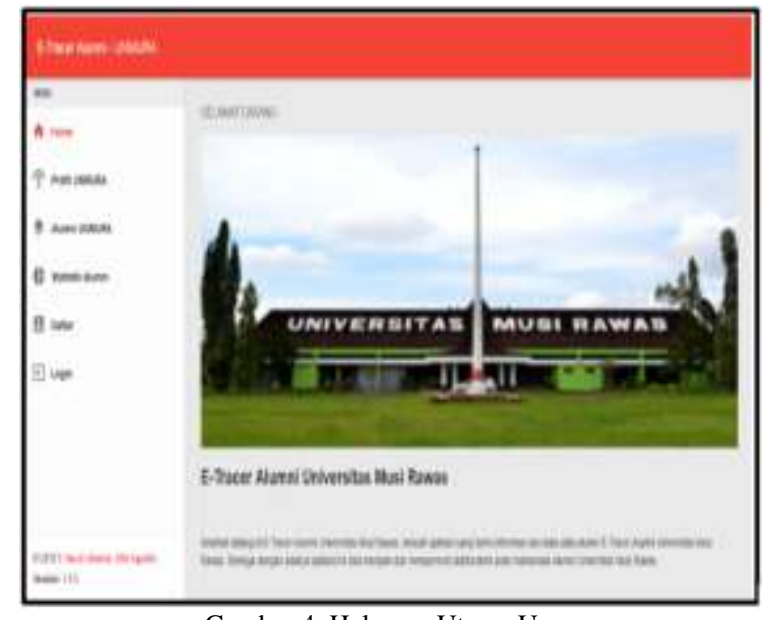

Gambar 4. Halaman Utama User

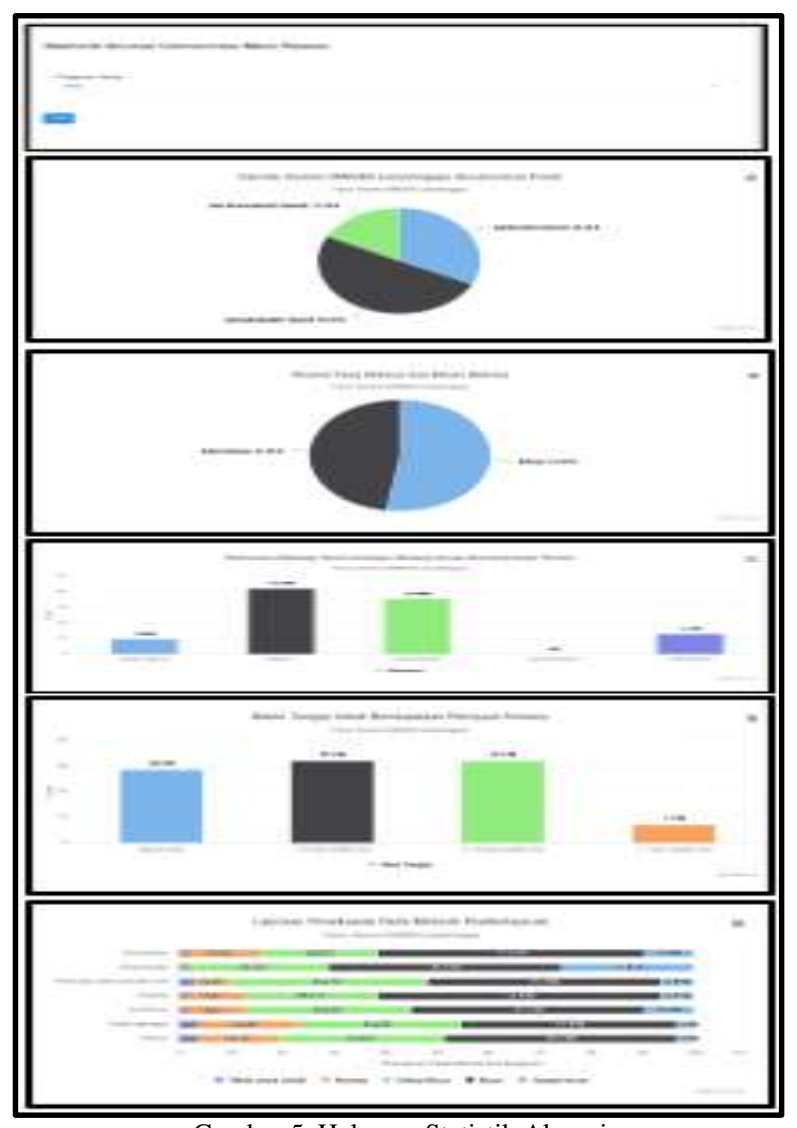

Gambar 5. Halaman Statistik Alumni

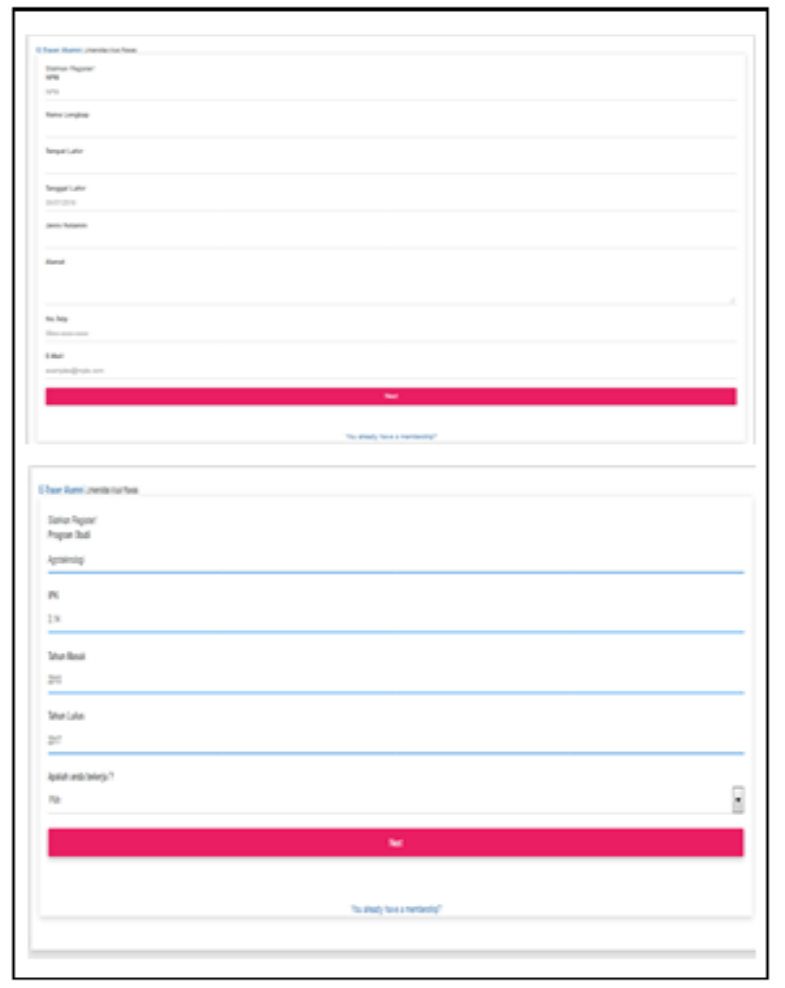

Gambar 6. Halaman Pendaftaran Alumni

1) Halaman Pengisian Kuisioner

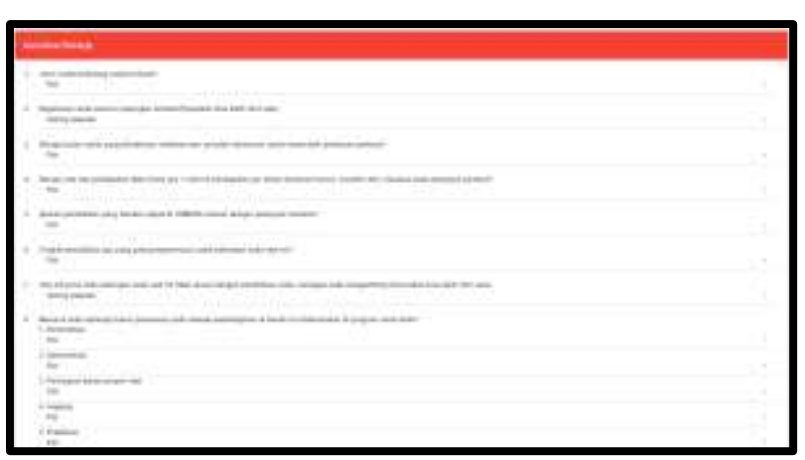

Gambar 7. Kuisioner Bekerja

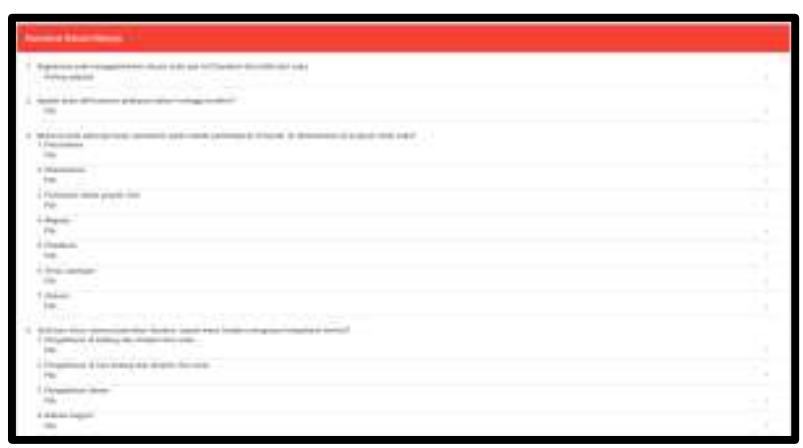

Gambar 8. Kuisioner Belum Bekerja

5. Kesimpulan

Jurnal Ilmiah Binary STMIK Bina Nusantara Jaya

Vol. 01 No. 01 Tahun 2019, ISSN : 2657-2117 


\subsection{Simpulan}

Dari hasil penelitian yang dilakukan sampai pembuatan sistem e-tracer study alumni pada Fakultas Pertanian Universitas Musi Rawas berbasis web mobile maka dapat disimpulkan bahwa:

1) Pada sistem e-tracer study terdiri dari tiga user yakni admin, alumni dan umum. Dimana setiap user memiliki hak akses yang berbeda.

2) Sistem ini merupakan sistem dinamis dan terintegrasi yang dapat mengumpulkan dan mengolah serta menyajikan data tracer study yang mengacu pada standar Dikti.

3) Web mobile dapat mempermudah user dalam penggunaannya karena dapat menyesuaikan perangkat mobile yang digunakan.

4) Dengan sistem ini alumni dapat memberikan saran kepada Fakultas Pertanian Universitas Musi Rawas dan juga menyediakan data yang informatif mengenai tracer study alumni dan berita lainnya.

\subsection{Saran}

Pada sistem e-tracer study alumni ini masih memiliki kekurangan pada kuisioner. Kuisioner yang diterapkan bersifat dinamis namun belum ada kuisioner dengan kategori kuisioner dan bidang yang berbeda. Untuk pengembangan selanjutnya diharapkan sistem e-tracer study alumni dapat menjadi lebih kompleks lagi dengan penambahan kuisioner dengan kategori kuisioner dan bidang yang berbeda.

\section{Daftar Rujukan}

[1] Karyono, Giat and Nandang Hermanto. 2013. "Rancang Bangun Sistem Tracer Study Online Pada STMIK AMIKOM PURWOKERTO." Semantik 3(1):126-33.

[2] Bakti, Very Kurnia, Mohammad Noval, and Eko Purnomo Bayu Aji. 2017. "Sistem Pre Kompilasi Data Tracer Studi Online Ditjen Belmawa Ristekdikti (Studi Kasus: Politeknik Harapan Bersama)." Jurnal Informatika: Jurnal Pengembangan IT 2(1):50-53.

[3] Dikti, Tracer Study. 2017. "Tracer Study." Retrieved November 10, 1BC (http://tracerstudy.dikti.go.id).

[4] (KBBI), Kamus Besar Bahasa Indonesia. 2018. "Pengertian Alumni." KBBI Online 1. Retrieved January 10, 2018 (https://kbbi.web.id).

[5] Pajak, Pusdiklat. 2017. "Membedakan Output Dan Outcome Pendidikan." Retrieved January 18, 2018 (http://www.bppk.kemenkeu.go.id).

[6] Abdurahman, Muhdar. 2016. "Sistem Informasi Jadwal Perkuliahan Berbasis Web Mobile Pada
Politeknik Sains Dan Teknologi Wiratama Maluku UtaraMuhdar Abdurahman Politeknik Sains Dan Teknologi Wiratama Maluku Utara." Indonesian Journal on Networking and Security 5(2):49-56.

[7] Rosa A.S and M. Shalahuddin. 2013. Rekayasa Perangkat Lunak. Informatika bandung.

[8] Yanto, Robi. 2016. Manajemen Basis Data Menggunakan MySQL. CV Budi Utama.

[9] Fathansyah. 2012. Basis Data. Revisi. 978-6028758-53-6.

[10] Raharjo, Budi. 2015. Mudah Belajar PHP Teknik Penggunaan Fitur-Fitur Baru Dalam PHP 5. Informatika bandung.

[11] Haryanto, Eri. 2015. "Queuing System Dengan Voice Untuk Rumah Sakit.” 5(2).

[12] Setyawan, Aziz. 2015. "Perancangan Mail Server Intranet Berbasis Web Base Dengan Optimalisasi Operasi Sistem Client." Teknik Komputer I(1):1-10.

[13] Lestanti, Sri and Ardina Desi Susana. 2016. "Sistem Pengarsipan Dokumen Guru Dan Pegawai Menggunakan Metode Mixture Modelling Berbasis Web." Jurnal Antivirus 10(2):69-77.

[14] Mustaqbal, M. Sidi, Roeri Fajri Firdaus, and Hendra Rahmadi. 2015. "( Studi Kasus : Aplikasi Prediksi Kelulusan SNMPTN )." Jurnal Ilmiah Teknologi Informasi Terapan 